口腔領域の末期癌患者の疼痛に対するケタミン

微量持続点滴静注について

吉田勇夫・且井誠・松矢篤三

浦出雅裕・五十嵐智一・栗本拓哉

西村恵司*·森本 㓮・宮崎 正

\title{
Micro-drip infusion of ketamine for the management of the pain in the oral cancer patients of terminal stage
}

\author{
Isao Yoshida - Makoto Usur - Tokuzo Matsuya \\ Masahiro Urade - Tomokazu Igarashi - Takuya Kurimoto \\ Keiji Nishimura* - Tsuyoshi Morimoto - Tadashi Miyazaki
}

\begin{abstract}
Three terminal-stage oral cancer patients received intravenous micro-drip administration of ketamine (Ketalar $(\mathbb{B})$ for pain management.

A combination of diazepam with ketamine was administered to the patients to prevent the side effects of ketamine such as hallucination, excitation and dementia, and analgesic and sedative effects were observed.

Two patients safely received long-term administration of ketamine, however ketamine was stopped in one patient because of side effects.

This approach suggests that combination use of ketamine and diazepam is useful for the relief of cancer pain.
\end{abstract}

Key words: micro-drip infusion of ketamine, cancer pain, terminal-stage cancer patients

緒言

癌に対する研究・治療の進歩にもかかわらず, 癌によ る死亡は，わが国の死因の第 1 位を占めている.

治療を終えた患者ですら，再発や転移に対する不安は 常に残る。ましてや，末期癌患者に扎いては，癌による 疼痛や死に対する恐怖などで，そのいらだちは，筆舌に つくし難い，さらにそのことは，患者の親族や医祭従事

大阪大学齿学部口腔外科学第 1 講座

(主任：宮崎 正教授)

* 大阪聥信病院歯科

（主任：待田順治医長）

The First Department of Oral and Maxillofacial Surgery, Osaka University Faculty of Dentistry (Chief: Prof. Tadashi Miyazaki)

* Department of Dentistry, Osaka Teishin Hospital (Chief: Dr. Junji Machida)

受付日：昭和59年11月26日
者へも大きな問題を投げかけている.

顎口腔領域における末期癌患者においては, 腫瘍の進 展に伴い, 顔貌の変形あるいは経口摂取の困難さなど大 きな障害を認める。加えて, 気道確保のため気管切開も 必要となり, 行動および会話などの制限も伴い, 苦痛は 計り知れない。

末期癌患者の疼痛に対するアプローチは、ペインクリ ニックリやホスピス2)など，近年積極的に行われるよう になってきてはいるが，除痛法として完全なものはな W.

今回, われわれは, 末期癌患者の疼痛に対し, 解離性 静脈麻配薬であるケタミン（商品名ケタラール，三共） の微量持続点滴静注を用い, その有用性について倹討し たので報告する。

\section{対象および投与方法（表）}

(1) 対 象

当科に入院した顎口腔領域の末期癌患者のうち 3 名を 
表 対象扰よび投与方法

\begin{tabular}{|c|c|c|c|c|c|}
\hline 症 例 & 年 龄 & 性 別 & 初診時診断名 & $\begin{array}{c}\text { ケタミン扰よびジゼバムの } \\
1 \text { 日使用量 }\end{array}$ & 使用期間 \\
\hline (1) & 55歳 & 男性 & $\begin{array}{l}\text { 舌 癌 } \\
\text { （扁平上皮癌） } \\
\mathrm{T}_{3} \mathrm{~N}_{0} \mathrm{M}_{0} \text { Stage } \mathbb{I I}\end{array}$ & 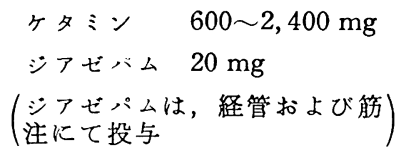 & 36 日 \\
\hline (2) & 60 歳 & 女性 & $\begin{array}{l}\text { 上顎洞 癌 (右) } \\
\text { (腺様 嵒胞 癌) }\end{array}$ & $\begin{array}{ll}\text { ケタミン } & 800 \sim 1,200 \mathrm{mg} \\
\text { シアゼパム } & 20 \sim 40 \mathrm{mg}\end{array}$ & 11日 \\
\hline (3) & 51 藏 & 男性 & 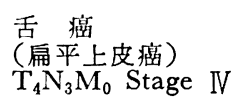 & $\begin{array}{ll}\text { ケタミン } & 600 \sim 1,800 \mathrm{mg} \\
\text { ジゼパム } & 30 \sim 40 \mathrm{mg}\end{array}$ & 89 日 \\
\hline
\end{tabular}

投与対象とした。

病理組織学的には, 扁平上皮癌が 2 名, 腺様垔胞癌が 1 名であった。

3 名のらち 2 名は, 一次治療を行った後, 再発または 転移をきたした症例であり，1名は，初診時に外科的療 法困難と判断された症例であった。

（2）投与方法

末梢静脈より静脈路を確保し，通常の補液に相当量の ケタミンを混入し微量持続点滴静注を行った。

その際,ケタミンの副作用である幻覚・興甥・錯乱な ぞの精神症状の発現を抑えるために, 適宜, 輸夜に混入 あるいは経管などにてジアゼパムを投与した。

\section{症例}

症例 $1:$ 55藏 男性. 昭和55年 7 月日初診. 診断名, 舌癌, $\mathrm{T}_{3} \mathrm{~N}_{0} \mathrm{M}_{0}$ Stage III (1978年 UICC 分類に 従 5).

昭和55年 8 月曰日より 8 月曰日にかけて, 放射線療法 (外部照射 ${ }^{60} \mathrm{Co} 3,000 \mathrm{rad}$ ), さらに 9 月回より 9 月 日にかけ，放射線療法（組織内照射 Ir hairpin 6,500 rad）施行するも，照射中より左側頸部に転移を認め， 左側全頸部郭清術を施行した。 その後, 原病巣に再発を 認め, 昭和56年 1 月回, 気管切開術 - 舌切除術 - 下䫇 骨部分切除術を施行したが，頸部への腫瑒の直接浸潤を 認め化学療法を行ったが奏効せず，除痛を主体とした療 法に㤎更した。

炤和56年 6 月より，ペンタゾシン笳拄・ジアゼパム経 管投与を行っていたが，腫瘍の増大に伴い疼痛も增大 し， 7 月初旬より，モルヒネ経管投与さらには筇注を併 用したが， 7 月下旬より，不眠を強く訴えたため，眠前 にドロペリドール点滴静注を試みた。しかし，效果が認 められず，昭和56年 8 月回上り，夜間のみ，ケタミン 证量点滴粼注を行った。輸液量 $200 \mathrm{ml}$ に, ケタミン150 $\mathrm{mg}$ ，アトロピン $0.5 \mathrm{mg}$ を混入し，入腿するまで全開で 滴下し, 入眠後, マイクロドロップ 18 滴/分にて維持し た. ジアゼパムは眠前に $5 \mathrm{mg}$ 経管にて投与した。点滴 中は, 傾眠状態にあり疼痛の訴えもなかった。しかし, 点滴終了後, 覚醒したあともしばらくは不快であったと の訴えがあり，8月回，一時中止した。

ケタミン使用期間中, 傾眠状態となった際血圧の軽度 上昇を認めたが問題となるものではなかった。

な拈，アトロピンに関しては，ケタミン使用以前より 迷走神経緊張光進を認めており, 症状発現予防のために 使用した。

ケタミン使用中止後，モルヒネ筋注の増量・ペンタゾ ミン筋注・ジアゼパム経管投与にて鎮痛を四っていた が, 疼痛拉よび不安の增大のため再び不眠を強く訴兄, 10月ロ日よりヶタミン微量持続点滴静注を終日投与とし て再開した。当初, ケタミンは 1 日量 $600 \mathrm{mg}$ にて開 始, ジアゼパムは 1 日 $15 \mathrm{mg}$ 経管投与扰よび眠前 $5 \mathrm{mg}$ 筋注にて投与した。

開始後しばらくは，鎮痛・鎮静効果を認めていたか， 経過とともにヶタミン初期使用量では意識が明膫となり 疼痛に対する訴えも強くなったため，効果を維持するた めケタミンの増量 ( 1 日量最高 $2,400 \mathrm{mg}$ ) および鎮痛 薬の併用を必要とした。 しかし，11月中旬より，胃管抜 去やその他の不穏な行動を認めるようになり，家族の希 望もあり，11月日日，中止した。

ケタミン使用期間中, 末梢静脈よりの静脈路確保部位 に早期から静脈炎を認め, 頻回の再確保が必要であっ た，その他, 軽度発熱, 血圧の軽度上昇を認めたが問題 となるものではなかった。

ケタミン使用中止後, モルヒネ筋注およびジアゼバム 経管投与にて除痛を図っていたか，肺炎を併発し，昭和 56 年12月日日，永眠した。

症例 2 : 60歳 女性. 昭和53年 8 月日初喰. 診断名，右側上顎洞癌 (腺様襄胞癌). 
昭和53年10月曰日，右侧上顎骨部分切除術を施行する も再発を認め，昭和54年，55年と再手術により腫湯摘出 を図ったが, 癌病巣の後方進展および肺転移を認めたた め, 外科的療法を断念し経過を追っていた。腫堭の增大 に伴い疼痛の增大拝よび癌病巣よりの出血を認めるよう になり，昭和58年 6 月日，再入院した。

入院直後は，インドメタシン坐薬使用によって除痛可 能であったが，6月目，疼痛による血圧上昇とともに 癌病巣より大量出血を認め, 気道確保のため気管切開術 を施行した，同時に，胃管による栄養補給を開始した。

その後, 疼痛による出血予防のため, インドメタシン 坐薬, ペンタゾシン扣よびヒドロキシジン䏩注を行って いたが，11月初旬より，腫瘍の急速増大により疼痛の訴 えも強くなってきたため，昭和58年11月—日より，ヶタ ミン・ジアゼハム微量持続点滴静注を試みた。

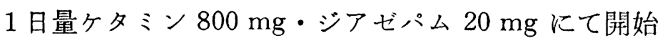
した，開始後 3 日間は, 呼びかけには反応するが傾眠状 態を呈し, 疼痛に対する訴えも認めないといら状態が得 られた。ただし，覚醒した際の話では，ずっと夢をみて いたとのことである. その後, 同療法の継続中, 徐々に 意識が明瞭となり，また，ときに軽い幻覚の出現をみた が，局所の疼痛に対する訴えは汪とんどなく中止するに は至らなかった。

しかし, 以前より認めていた神経性胃潰瘍の再発を思 わせる腹痛を訴えるようになり，ペンタゾシンおよびブ チルスコポラミン筋注などを必要とした。ささらにべッ ト上であばれる，あるいは，自ら胃管を引き抜くなどの 不穏行動を認めたため，11月日，1 日量ケタミン 1,200 $\mathrm{mg}$ ・ジアゼハムム $40 \mathrm{mg}$ に増量するも効果なく, 11 月 22 日, 中止した。

以後, モルヒネ・ペンタゾシン・ジアゼバムなどの筋 注により除痛を図り，現在も入院中である。

症例 3: 51歳 男性. 昭和58年 1 月回初診. 診断名, 舌癌. $\mathrm{T}_{4} \mathrm{~N}_{3} \mathrm{M}_{0}$ Stage $\mathrm{IV}$.

腫勛の進展度を考えると外科的療法は困難であり，乙 かも，患者は以前交通事故に遭遇して以来，認識力など が低下して扣り，親族との話し合いで除痛を主眼におい た治療方針とした。

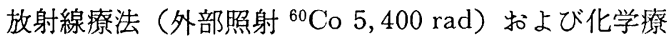
法（ペプロマイシン $180 \mathrm{mg}$ ) にて腫瘍の縮小ならびに 疼痛の軽減を認め, 外来にて経口抗癌剤执よびジクロフ ェナック投与にて経過をみていたが，重場の增大に伴い 疼痛の増大および與燕下困難による癷養状態の悪化を認 め, 昭和58年 10 月曰日，入院した。

点滴および胃管よりの栄養補給によって，栄症状態の 改善を図っていたが，11月ロ日，誤飲によると考えられ る気道閉塞のため昏睡に陥り，気管切開術を施行した。

意識回復後，局所の疼痛を強く訴えるようになり，11 月日より，ペンタゾシン筋注およびジアゼパム経管投
与を開始した。しばらくは，鎮痛効果を認めていたが， 1 日の鎮痛薬使用回数が增加し，また，ベット上での体 動も激しくなり, 付き添いの不安感も增し, 看護の面も 考虑に入れ，炤和58年11月回より，扣もに鎮静を図る 目的でケタミン・ジアゼパム微量持続点滴静注を開始し た。

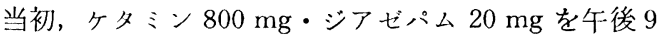
時より翌朝午前 9 時までの半日間使用した。使用中，患 者は，㖤眠状態を呈し疼痛の訴える認めなかった。昼間 は，ペンタゾシン筋注にて除痛を図ったが，効果が不十 分であり，また，体動も制御できないため，12月日日よ り，1日量ケタミン $1,200 \mathrm{mg}$ ・ジアゼハムム $40 \mathrm{mg}$ にて 終日投与した。

開始後しぱらくは，問いかけには反応するが体動はほ とんどなく疼痛に対する訴えもないといら良好な状態が 得られた。しかし，徐々に意識が明膫となり，しかも， 疼痛を訴えたしたため，12月日より，ケタミンの増 量（1 日量 $1,400 \mathrm{mg}$ ) およびペンタゾシン筋注併用を 行った。この状態で疼痛および体動は制御されていた が，静脈炎のため末梢䋫脈よりの静脈路確保に支障をき たしてきたため, 昭和59年 1 月回，ヶタミン・ジアゼ パム微量持続点滴静注を一時中止した。

中止後数時間して，患者の体動掞よび疼痛の訴えが非 常に強くなり，同㞠法の鎮痛・鎮静効果に打ける有用性 が再認識された。

その後，モルヒネ筋注打よびペンタゾシン筋注にて様 子をみたが，鎮痛・鎮静効果が十分に得られず，1月ロ 日より,ケタミン・ジアゼパム微量持続点滴静注を再開 し，同時に，モルヒネ筋注を併用した。1日量ケタミン $600 \mathrm{mg}$ ・ジアゼハムム $30 \mathrm{mg}$ より開始するも十分な効果 が得られなかったため,ケタミンの増量（1 日量最高 $1,800 \mathrm{mg})$ 扣よびモルヒネ恰注回数の増加を行い鎮痛・ 鎮静を図った。その後, 全身状態の悪化に伴いヶタミン の使用量を減量し, 昭和59年 2 月日, ケタミン・ジア ゼパム微量持続点滴静注を中止した。

な扣，使用期間中，軽度の発熱を認めていたが，中止 後 $4 \sim 5$ 日にて平熱に復した。

以後, 著明な体動もなく, 疼痛に対してもモルヒネ竻 注のみで十分であったが，昏睡および呼吸不全のため，

3 月回, 鎮痛薬の使用中止, 昭和 59 年 4 月日日，永眠 した.

\section{考察}

末期癌患者の除痛法として，坐薬あるい:非麻薬性鎮 痛薬・磨薬性鎮痛薬・精神安定楽などの注射が多く行わ れている。これらの方法は，簡便で効果もある程度認 め，当科に沶いても，主としてこれらの方法を用いてい る. 
しかし, これらの方法は, 疼痛の増大に従い効果が不 十分となる場合や，使用量の增加・長期使用など伴う 耐性や啫癖などの問題が生じてくる。

最近では，ペインクリニック リ，ホスピス2)など末期 癌患者の疼痛に対しての関心も高まっている.

ペインクリーックの1つとして, 神経ブロック（硬膜 外ブロック・くも膜下腔ブロックなど)・手術的除痛法 などが工夫され效果をあげているが，これらとて完全な ものではなく，また，手技的な問題もあり十分には普及 していない現状である。

末期癌患者の疼痛は, ターミナルケアの概念" ${ }^{3)}$ からす ると身体的苦痛の 1 症状といえる。 そして, 疼痛の他に さまざまな苦痛が重なり，さらに，不安・怒り・いらた ち・孤独などの精神的苦痛も加わり，全体的苦痛として 現れる。このよらな状沉を十分にふまえた上で，患者へ の対処が必要であると思われる。

今回, 対象となった患者はいずれる腫掦が准展してお り, 癌による疼痛は想像を絶すると思われた。ささらに, 気管切開による行動, 会話などの制限, 経鼻での胃管に よる栄養補給や顔貌の変形などの身体的苦痛は, 精神的 苦痛と相関し, 全体的苦痛をも增大させている. そこ で, 癌による疼痛を怙さえるばかりでなく, 精神的苦痛 も沶さ光ることによる全体的苦痛の軽減が必要であり， 持続的な鎮痛・鎮静効果が得られる方法が望まれた。そ こで,われわれは, 静脈麻酔薬であり, しかも, 強い鎮 痛作用を有するケタミンの使用を試みた。

ケタミンは, 呼吸抑制・循環抑制が少なく強い鎮痛作 用を有する解離性静脈麻酔薬である。単独に用いた場 合, 精神症状の発現などの副作用が現れやすいが, 秦野 ら゙)により開発されたケタミン・ジアゼパム微量点滴静 注法に沶いては, 副作用の発現も少ないとされている. 鎮痛作用に関しては，体性痛に対して強い効果を有する とされ，内臓痛に対しては効果がないとされていたが， 内䒽痛に対しても有効であることが，秦野ららによって 実証されている。

末期癌患者の疼痛に対するケタミンの応用は, 田中6) が初めて報告し，その後も，福田ら ${ }^{7 \sim 11}$ が報告し，有効 な結果が得られたと述べている。それらの怙るな方法 は, ケタミン・ジアゼハム微量持続点滴静注といら方法 である。

今回, われわれは, 通常の補液に相当量のケタミンを 混入し, 末梢静脈路より微量持続点滴静注を行うといら 方法を用いた，通常，ケタミンの副作用である精神症状 の発現子防のためにジアゼハムを同時に混入するが, 症 例 1 に扎いては, ジアゼパムは補液に混入せず, 経管括 よび筋注にて投与した。 なお，症例 2,3 においては, 通常どおりケタミン・ジアゼパム微量持続点滴静注を行 った。

ジアゼパムを経管および筋注にて投与した症例 1 で
は，開始後しばらくは精神症状の 発現を認めなかった が, 効果維持のためのケタミン增量もあり, 最終的には 精神症状によると考えられる不榣な行動が出現し, 中止 せざるを得なくなった。この症例において，ヶタミン。 ジアゼバム微量持続点滴静注を試みておれば,ささらに継 続して使用できていたのかもしれない.しかし，症例2 に执いては, ケタミン・ジアゼパム微量持続点滴彩註を 行ったにもかかわらず，使用開始後比較的早期に精神症 状が発現し, 中止するに至った。 このような個々の症例 により，ジアゼパムを用いてもケタミンによる精神症状 が抑えられない場合もあり，今後さらに，投与方法の工 夫が必要であると思われた。

ケタミンの使用期間については, 報告されている症例 の多くは短期使用例である。長期使用例に関しては柴田

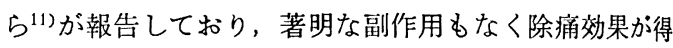
られたと述べている，今回の症例においても，3例中 2 例において，36日，89日と比較的長期にわたる投与日数 を得ることができた。そして，この 2 例について，拈拉 むね満足のいく鎮痛・鎮静効果が得られた。

しかし，その効果を維持するためには，ヶタミンの增 量および他の鎮痛法の併用を必要とした。これは, 経過 とともに, 同一量のケタミンでは，患者の意識が明䐲と なり疼痛の訴えも強くなったためである. Slogoff ら ${ }^{12)}$ は,ケタミンに対して耐性が生じるとしており，この耐 性が効果減弱の一因として推察される。また，睡瘍の進 展により疼痛が増大したこと、ケタミンによっては抑兄 られない疼痛が生じたことなども一因として考光られ る。

癌性疼痛の発生機序はさまざまであり，また，腫瘍の 増大や転移により疼痛を認める部位もさまざまである。 したがって，ケタミンのみで除痛を図ることは困難であ り, 必要に応じての他の除痛法を併用することが望まし い.

また, ケタミンの長期使用にあたり，䋛脈路確保部位 に静脈炎を生じ, 静脈路確保に困難を生した。静脈炎に 関して，現在まで短期使用例はもとより長期使用例に拉 いても，その報告はない。柴田ら ${ }^{11} は$ は, 静脈路確保に祭 し，中心静脈・末梢静脈いずれも支障はないとしている が，多くは中心静脈上り投与されている．今回の症例に おいては，いずれも末梢静脈より確保しており，静脈炎 の一因となった可能性は否定できない，短期使用におい ては，さほど問題とならないか，長期使用においては， 隣脈路確保についても考虑が必要と思われる.

その他, ケタミンの使用中, 軽度の発熱などを認めた が問題となるものではなかった。

末期癌患者の除痛対策の 1 つとして今回使用したケタ ミン微量持続点滴静注法は, きわめて簡便であり, しか も，投与量の調節により患者の意識状態もある程度調節 できるという利点もある。ささらに，鎮痛・鎮静効果に対 
しても，お扰むね満足のいく結果が得られた。

しかし、ケタミンの副作用である精神症状をジアゼパ ム使用にても完全には抑えられない場合もあり，また， 疼痛に対しても単独の使用では制御できず，他の鎮痛法 の併用を必要とすることも多く，今後さらに工夫する余 地があると思われる。

しかし，末期癌患者の除痛法として完全なものがない 現状に拈いて，症例の選択を行えば，除痛法の一つとし て試みてよいと思われる。

結語

(1) 顎口腔領域の末期癌患者 3 名の疼痛に対して, ケ タミン微量持続点滴静注を試みた。その際，ケタミンの 副作用である精神症状の発現子防のため，ジアゼハムを 併用した。

（2） 3 名中 2 名において，比較的長期にわたり使用す ることができた。 そして，扣扣む满足できる鎮痛・鎮 静効果が得られた。

（3）ケタミンの投与に対し, 今後さらに工夫する余地 はあるが，症例を選択すれば，末期癌患者の除痛法の 1 つとして試みてよいと思われる。

\section{引用 文 献}

1）播磨晃宏，森 健二郎：進行癌はどこむでなお せるかー一゚インクリニックの立場から——

臨婦産 31: 41-45 1977.
2）原義雄，千原 明：聖䍮ホスピスに扣ける夕 一ミナルケア.彭断と治療 71：999-1002 1983.

3）岡安大仁：ターミナルケアの実際。診断と治療 71: 981-987 1983.

4) 秦野 滋, Keane, M.D., 他：開心術に対する シアゼバム・ケタミン麻酔——特に微量持続点 滴法について——. 麻酔 26：560-569 1977.

5) 嗪野濼，松村美代，他：腹部手術に対するシ アゼバムケタミンの微量持続点滴麻酔法—— 1,000例の臨床経験から一一. 臨床麻酔 1：2462591977.

6）田中亮：ケタラールの応用，悪性腫痬末期患 者の疼痛対策として，ケタラール研究会：6-9 1970.

7）福田悦夫, 後町千秋, 他：癌末期疼痛一一ヶ ミン微量持続点滴这入法について一。. 医㾻 35: 548-587 1981.

8）野一色录晴：癌性疼痛扣よび不安状態に対寸る ケタミン・アミトリプチリン併用療法。岡山大 学温泉研究所報告 51：21-23 1981.

9）種田征四郎，今村元彦，他：末期卵单癌の疼痛 対策としての塩酸 Ketamine 微量点滴注入法. 新薬々臨床 32: 1472-1476 1983.

10）山岡久泰：癌末期疼痛に対するケタミンの持結 点滴法について。 日赫医学 35：175-178 1983.

11）柴田 好，奥山修司：末期瘦の疼痛に対する アゼハムムケタミンの長期微量点滴狰注法。旭 市病誌 16: 1-5 1984.

12) Slogoff, S., Allen, G.W., et al.: Clinical experience with subanesthetic Ketamine. Anesth Analg 53: 354-358 1974. 